\title{
The effects of type of protein and fibre fermented in vitro with different pig inocula on short-chain fatty acids and amines concentrations
}

\author{
M. Taciak', M. Barszcz, A. Tuśnio, I. Bachanek, B. Pastuszewska and J. Skomiał \\ The Kielanowski Institute of Animal Physiology and Nutrition, Polish Academy of Sciences, 05-110 Jabłonna, Poland
}

KEY WORDS: casein, carbohydrates, faeces, colonic digesta, in vitro fermentation, potato protein, proteolysis, pig inoculum
Received: 17 December 2014

Revised: $\quad 29$ July 2015

Accepted: 9 September 2015
${ }^{1}$ Corresponding author: e-mail: m.taciak@ifzz.pl

\begin{abstract}
In an in vitro experiment with pig inoculum, the main and interactive effects of type of protein and fibre on the concentrations of short-chain fatty acids (SCFA) and amines as the end products of fermentation and proteolysis were determined. The effects of inoculation with colonic digesta (C) sampled post mortem or with freshly voided faeces $(F)$ as the sources of microflora, and of 24- vs 48-h periods of incubation, were also estimated. Potato protein and casein were fermented each with cellulose, pectin, or raw potato (resistant) starch. Each set of fermentation was repeated six times. The total SCFA concentration was greater after $C$ than $F$ fermentation, regardless of the substrates. It was the greatest after fermentation of both proteins with potato starch and greater after fermentation of all carbohydrates with casein than with potato protein. The largest concentrations of isobutyric and isovaleric acids were found after fermentation of casein with cellulose, but only with $C$ $(P=0.040$ and $P=0.030$ for interaction, respectively). Also, a butyrogenic effect of potato starch was found only after $C$ fermentation and was greater after 48 than $24 \mathrm{~h}$. The total amines concentration after $\mathrm{C}$ and $\mathrm{F}$ fermentation of potato protein with all fibres was the same, while after $C$ fermentation of casein it was affected by the type of fibre $(P=0.001$ and $P=0.000$ after 24 and $48 \mathrm{~h}$, respectively). It was very high with cellulose, lower with starch and the lowest with pectin. It may be concluded that in vitro bacterial proteolysis is greatly affected by the interaction of type of protein and fibre. Forty-eight-hour fermentation with colonic digesta seems to be more discriminative than $24-h$ fermentation and colonic digesta is a more discriminative pig inoculum than faeces.
\end{abstract}

\section{Introduction}

The rate of fermentation and profile of shortchain fatty acids (SCFA) in the hindgut of monogastric animals are affected mainly by the composition and characteristics of dietary carbohydrates, but also of protein (Montagne et al., 2003). Cellulose is a weakly fermented substrate, whereas pectin and resistant starch are fermented more intensively, the latter being known as a butyrogenic compound (Bindelle et al., 2008). Protein resistant to enzymatic digestion and passing from the ileum to the large intestine serves as a source of nitrogen for bacteria and promotes production of SCFA, particularly of branched-chain fatty acids (Morita et al., 2004; Taciak et al., 2010; Richter et al., 2013), but also of ammonia, amines, hydrogen sulphide, and phenolic and indolic compounds, some of which are consi- 
dered to be toxic. Feeding resistant protein along with easily fermentable fibre may depress proteolysis, decrease the concentration of protein metabolites, and alleviate their potential negative effects (Swanson et al., 2002; Jeaurond et al., 2008; Pieper et al., 2012).

The effect of interaction between types of fibre and protein on the activity of microflora and concentration of metabolites in the gut are not fully recognized. Knowledge on the consequences of these interactions is scarce because in vivo studies on nutrient digestion and fermentation in the hindgut are difficult and expensive. Therefore, in vitro techniques have been developed and are now extensively used, mainly in pathophysiological studies in humans but also in nutritional investigations in monogastric animals (Bourquin et al., 1992; Coles et al., 2005; Mallillin et al., 2008; Dierick et al., 2010; Jha et al., 2011; Tabernero et al., 2011).

Among important factors affecting the results of in vitro fermentation and their relevance to in vivo conditions are the source of inoculum and duration of incubation (Coles et al., 2005). In pigs, caecal, or more often faecal, inocula are employed and considered a source of colonic microflora. The last assumption is controversial, however.

Feeding more fermentable fibre may promote favourable SCFA yield and profile, but may also influence the synthesis of potentially harmful protein metabolites. Therefore, the purpose of the present study was to examine the effect of differently digested fibre and protein on in vitro fermentation processes and the concentration of SCFA and amines. Moreover, the rate and outcome of fermentation were determined under different conditions of the processes, i.e. source of inoculum and duration of fermentation. In the present study, highly digestible casein and potato protein, which has lower ileal and total digestibility (Morita et al., 1998; Tuśnio et al., 2011), were used as nitrogen sources. As fibre sources, poorly fermented cellulose, more intensively fermented pectin and raw potato starch (representing resistant starch) were compared.

\section{Material and methods}

\section{Experimental design}

In $2 \times 3$ factorial design, each of 6 combinations of two proteins (casein and potato protein) with three fibres (cellulose, pectin, resistant starch) was fermented for 24 and $48 \mathrm{~h}$ with either colonic or faecal inoculum. Fermentation of each substrate combination was repeated six times $(n=6)$.
After fermentation, the $\mathrm{pH}$ and the SCFA and amine concentrations were determined in the medium.

\section{Protein and fibre sources}

Food-grade casein was purchased from a milk cooperative, Mlekpol (Zambrów, Poland), feed-grade commercial potato protein was supplied by Trouw Nutrition Company (Grodzisk Mazowiecki, Poland). Cellulose Arbocel was obtained from Rettenmaier \& Söhne GmbH (Rosenberg, Germany), apple pectin from ZPOW Pektowin Sp. z o.o. (Jasło, Poland) and food-grade potato starch was purchased from Potato Industry Company Trzemeszno S.A. (Trzemeszno, Poland).

\section{In vitro fermentation}

Six combinations of casein or potato protein with cellulose, pectin, or potato starch were fermented for 24 or $48 \mathrm{~h}$ with inoculum prepared from colonic digesta $(\mathrm{C})$ or faeces $(\mathrm{F})$ sampled from different pigs. Each fermentation was repeated with freshly prepared inoculum six times $(n=6)$. Inoculum $\mathrm{C}$ was prepared from colonic digesta collected from two pigs per repetition, shortly after slaughter, whereas inoculum $\mathrm{F}$ was prepared from freshly voided faeces from two other pigs maintained in the experimental fattening unit. Digesta and faeces were transferred to the laboratory, pooled and processed in the same way under anaerobic conditions. The material was diluted 1:5 (w/v) with saline, filtered through cloth and $4 \mathrm{ml}$ of filtrate was added to a conical flask containing $0.2 \mathrm{~g}$ of protein, $0.5 \mathrm{~g}$ of fibre and $26 \mathrm{ml}$ of medium. Medium was prepared according to Campbell and Fahey (1997) and its composition is given in Table 1. Sealed flasks were maintained at $39^{\circ} \mathrm{C}$ in an incubator and stirred gently with a magnetic stirrer. After 24 or $48 \mathrm{~h}$, fermentation was terminated, $\mathrm{pH}$ measured, and the content of the flask was centrifuged (6000 rpm, $20 \mathrm{~min}, 4^{\circ} \mathrm{C}$ ). The supernatant was frozen and kept at $-20^{\circ} \mathrm{C}$ until analyses.

\section{Amines analysis}

The HPLC method used in the present study was adapted from that described by Bailey et al. (2003). One millilitre of supernatant was diluted 1: $4(\mathrm{v} / \mathrm{v})$ with acetone:water $(2: 1)$, and the resulting solution was made basic by the addition of $1 \mathrm{ml}$ of borax buffer (3.81 g sodium tetraborate in $100 \mathrm{ml}$ of distilled water adjusted to $\mathrm{pH} 10.5$ with $10 \mathrm{M}$ sodium hydroxide). The internal standard, heptylamine, was added to a final concentration of $5 \mu \mathrm{g} \cdot \mathrm{ml}^{-1}$. The amines were derivatized with $1 \%$ dansyl chloride in acetone at $65^{\circ} \mathrm{C}$ for $25 \mathrm{~min}$ and then extracted 
Table 1. Composition of medium

\begin{tabular}{lc}
\hline Component & $\begin{array}{c}\text { Concentration } \\
\text { in medium, } \mathrm{ml}^{-\mathrm{F}^{-1}}\end{array}$ \\
\hline Solution $\mathrm{A}^{1}$ & 330.0 \\
${\text { Solution } \mathrm{B}^{2}}$ & 330.0 \\
Trace minerals solution $^{3}$ & 10.0 \\
Water-soluble vitamins solution $^{4}$ & 20.0 \\
Folate: biotin solution $^{5}$ & 5.0 \\
Riboflavin solution $^{6}$ & 5.0 \\
Haemin solution $^{7}$ & 2.5 \\
Short-chain fatty acids mix $^{8}$ & 0.4 \\
Resazurin $^{9}$ & 1.0 \\
Distilled $\mathrm{H}_{2} \mathrm{O}$ & 296.0 \\
\hline
\end{tabular}

${ }^{1}$ composition, g $\cdot \mathrm{I}^{-1}: \mathrm{NaCl} 5.4, \mathrm{KH}_{2} \mathrm{PO}_{4} 2.7, \mathrm{CaCl}_{2} 0.1377, \mathrm{MgCl}_{2}$. $6 \mathrm{H}_{2} \mathrm{O} \quad 0.12, \mathrm{MnCl}_{2} \cdot 4 \mathrm{H}_{2} \mathrm{O} \quad 0.06, \mathrm{CoCl}_{2} \cdot 6 \mathrm{H}_{2} \mathrm{O} \quad 0.06,\left(\mathrm{NH}_{4}\right)_{2} \mathrm{SO}_{4} 5.4 ;$ ${ }^{2}$ composition, $\mathrm{g} \cdot \mathrm{I}^{-1}: \mathrm{K}_{2} \mathrm{HPO}_{4} 2.7$; ${ }^{3}$ composition, $\mathrm{mg} \cdot \mathrm{I}^{-1}$ : ethylenodiaminetetraacetic acid (disodium salt) $500, \mathrm{FeSO}_{4} \cdot 7 \mathrm{H}_{2} \mathrm{O} 200$, $\mathrm{ZnSO}_{4} \cdot 7 \mathrm{H}_{2} \mathrm{O} 10, \mathrm{MnCl}_{2} \cdot 4 \mathrm{H}_{2} \mathrm{O} 3, \mathrm{H}_{3} \mathrm{PO}_{4} 30, \mathrm{CoCl} \cdot 6 \mathrm{H}_{2} \mathrm{O} 20$, $\mathrm{CuCl}_{2} \cdot 2 \mathrm{H}_{2} \mathrm{O} 1, \mathrm{NiCl}_{2} \cdot 6 \mathrm{H}_{2} \mathrm{O} 2, \mathrm{Na}_{2} \mathrm{MoO}_{4} \cdot 2 \mathrm{H}_{2} \mathrm{O} 3 ;{ }^{4}$ composition, $\mathrm{mg} \cdot \mathrm{I}^{-1}$ : thiamin $\cdot \mathrm{HCl}$ 100, D-pantothenic acid 100, niacin 100, pyridoxine 100 , p-aminobenzoic acid 5 , vit. $\mathrm{B}_{12} 0.25 ;{ }^{5}$ composition, $\mathrm{mg} \cdot \mathrm{l}^{-1}$ : folic acid 10, D-biotin 2, $\mathrm{NH}_{4} \mathrm{HCO}_{3} 100 ;{ }^{6}$ composition: riboflavin, $10 \mathrm{mg} \cdot \mathrm{I}^{-1}$ in $5 \mathrm{mmol} \cdot \mathrm{I}^{-1}$ of HEPES; ${ }^{7}$ composition: haemin, $500 \mathrm{mg} \cdot \mathrm{l}^{-1}$ in $10 \mathrm{mmol} \cdot \mathrm{H}^{-1}$ of $\mathrm{NaOH} ;{ }^{8}$ composition: $200 \mathrm{ml} \cdot \mathrm{H}^{-1}$ each of acetic acid, isobutyric acid, valeric acid, propionic acid, isovaleric acid, butyric acid; ${ }^{9}$ composition: resazurin, $1 \mathrm{~g} \cdot \mathrm{H}^{-1}$ in distilled $\mathrm{H}_{2} \mathrm{O}$

using SEP-PAK C18 solid-phase extraction cartridges $(6 \mathrm{ml}, 500 \mathrm{mg}$; Waters Ltd., Watford, Hertfordshire, UK). Separation was carried out using a Finnigan Surveyor Plus liquid chromatograph (Thermo Scientific, San Jose, USA) with a photodiode array detector operated at $254 \mathrm{~nm}$. Chromatographic separation was achieved with a Waters Symmetry Shield $\mathrm{RP}_{18}$ column $(150 \times 3.9 \mathrm{~mm}$ i.d., particle size $5 \mu \mathrm{m})$ preceded by a Waters Symmetry Shield $\mathrm{RP}_{18}$ guard column $(20 \times 3.9 \mathrm{~mm}, 5 \mu \mathrm{m})$. The gradient elution system with a mixture of $5 \%$ acetonitrile (A) and $100 \%$ acetonitrile (B) was used at a constant flow rate of $0.4 \mathrm{ml} \cdot \mathrm{min}^{-1}$. The gradient elution programme was: $0-5 \min (25 \% \mathrm{~B}), 5-10 \mathrm{~min}(45 \% \mathrm{~B})$, $10-15 \min (60 \% \mathrm{~B}), 15-42 \mathrm{~min}(80 \% \mathrm{~B})$ followed by 4 min to reach the initial conditions and mobile phase stabilization. Samples were injected $(1 \mu l)$ in duplicate onto the column. Amines were identified and quantitated from a standard curves constructed from the pure compounds.

\section{SCFA analysis}

The SCFA analysis was performed according to the procedure described by Barszcz et al. (2011) on a HP 5890 Series II gas chromatograph (Hewlett Packard, Waldbronn, Germany) with a flame-ionization detector and Supelco Nukol fused silica capillary column $(30 \mathrm{~m} \times 0.25 \mathrm{~mm}$ internal diameter, film $0.25 \mathrm{~mm}$ ). Helium was used as the carrier gas. The concentrations of individual SCFA were estimated in relation to an internal standard using a mixture of SCFA standard solutions.

\section{Statistical analysis}

The results were subjected to two-factorial ANOVA followed by the post-hoc Tukey's HSD test using the STATGRAPHICS ${ }^{\circledR}$ Centurion XVI ver. 16.1.03 statistical package (StatPoint Technologies, Inc., Warrenton, Virginia, USA). The effects were considered to be significant at $P \leq 0.05$.

\section{Results}

\section{SCFA and amines concentrations after fermentation with colonic inoculum}

The total SCFA concentration (Table 2) was affected by fibre both after 24 and $48 \mathrm{~h}(P=0.014$ and $P=0.000$, respectively) and by protein after $48 \mathrm{~h}$ of fermentation $(P=0.022)$. With both proteins, total SCFA was the greatest when starch was the substrate, and with all fibres, SCFA was greater on casein than on potato protein. All particular acids were or tended to be affected by fibre either after 24 and $48 \mathrm{~h}$, or only after longer fermentation (propionic acid). Concentrations of isobutyric and isovaleric acids were greater when casein was fermented with cellulose than with starch and pectin $(P=0.040$ and $P=0.030$, respectively, for interaction after $48 \mathrm{~h}$ ).

The total concentration of amines was affected by protein $(P=0.001$ and $P=0.000)$, fibre $(P=0.001$ and $P=0.000)$ and interaction, both after 24 and $48 \mathrm{~h}$ of C fermentation (Table 3). The effect of fibre on the total amine concentration was very small when potato protein was the substrate and remarkably large when casein was fermented. Fermentation of casein with cellulose yielded far greater amounts of amines than with starch and pectin and about 10 times more amines than fermentation of potato protein with cellulose. The differences among the total amines concentrations were mainly due to the contribution of putrescine, 1,4-diaminoheptane and phenylethylamine (Table 4).

The concentrations of the majority of amines were rather low, ranging from below 1 to about $6 \mu \mathrm{mol} \cdot 100 \mathrm{ml}^{-1}$, and significant effects of protein, fibre or interactions were of a small magnitude. The exceptions were the high concentrations of putrescine, 1,4-diaminoheptane and phenylethylamine after fermentation of casein with cellulose and with potato starch, but not with pectin. The concentrations of these amines after $24 \mathrm{~h}$ fermentation of casein with cellulose were 69,69 and $10 \mu \mathrm{mol} \cdot 100 \mathrm{ml}^{-1}$, respectively and increased to 107, 108 and 26 after $48 \mathrm{~h}$. The 24-h fermentation of 
Table 2. The $\mathrm{pH}$ of the medium and SCFA $\left(\mathrm{mmol} \cdot \mathrm{F}^{-1}\right)$ concentration after 24 and $48 \mathrm{~h}$ fermentation with colonic inoculum

\begin{tabular}{|c|c|c|c|c|c|c|c|c|c|c|c|c|c|c|c|c|}
\hline \multirow{2}{*}{$\begin{array}{l}\text { Protein/ } \\
\text { fibre }\end{array}$} & \multicolumn{2}{|l|}{$\mathrm{pH}$} & \multicolumn{2}{|l|}{$\begin{array}{l}\text { Total } \\
\text { SCFA }\end{array}$} & \multicolumn{2}{|l|}{$\begin{array}{l}\text { Acetic } \\
\text { acid }\end{array}$} & \multicolumn{2}{|c|}{$\begin{array}{l}\text { Propionic } \\
\text { acid }\end{array}$} & \multicolumn{2}{|c|}{$\begin{array}{l}\text { Isobutyric } \\
\text { acid }\end{array}$} & \multicolumn{2}{|c|}{$\begin{array}{l}\text { Butyric } \\
\text { acid }\end{array}$} & \multicolumn{2}{|c|}{$\begin{array}{l}\text { Isovaleric } \\
\text { acid }\end{array}$} & \multicolumn{2}{|l|}{$\begin{array}{l}\text { Valeric } \\
\text { acid }\end{array}$} \\
\hline & 24 & 48 & 24 & 48 & 24 & 48 & 24 & 48 & 24 & 48 & 24 & 48 & 24 & 48 & 24 & 28 \\
\hline PP PEC & 3.32 & 3.35 & 3.88 & 3.78 & 1.88 & 1.85 & 0.64 & 0.63 & 0.33 & 0.32 & 0.47 & 0.44 & 0.27 & 0.26 & 0.29 & 0.28 \\
\hline PP CEL & 4.84 & 4.95 & 4.19 & 4.87 & 2.35 & 2.83 & 0.65 & 0.82 & 0.31 & 0.32 & 0.40 & 0.40 & 0.25 & 0.27 & 0.23 & 0.23 \\
\hline PP STA & 3.76 & 3.68 & 7.12 & 10.94 & 2.81 & 5.93 & 1.03 & 0.72 & 0.25 & 0.29 & 1.93 & 2.55 & 0.21 & 0.22 & 0.89 & 1.22 \\
\hline CAS PEC & 3.40 & 3.33 & 4.65 & 4.99 & 2.57 & 2.98 & 0.75 & 0.67 & 0.32 & 0.32 & 0.48 & 0.48 & 0.27 & 0.26 & 0.26 & 0.28 \\
\hline CAS CEL & 5.52 & 5.72 & 7.09 & 8.82 & 2.78 & 2.94 & 1.03 & 1.15 & 0.65 & 0.84 & 1.16 & 1.80 & 0.97 & 1.41 & 0.50 & 0.68 \\
\hline CAS STA & 3.90 & 3.73 & 12.04 & 16.12 & 5.74 & 7.78 & 1.01 & 1.09 & 0.35 & 0.37 & 2.88 & 4.43 & 0.40 & 0.40 & 1.66 & 2.05 \\
\hline SEM & 0.09 & 0.08 & 1.75 & 1.75 & 0.59 & 0.89 & 0.23 & 0.14 & 0.08 & 0.10 & 0.70 & 0.80 & 0.16 & 0.22 & 0.40 & 0.46 \\
\hline \multicolumn{17}{|l|}{$P$-values } \\
\hline protein & 0.003 & 0.002 & 0.055 & 0.022 & 0.009 & 0.167 & 0.410 & 0.039 & 0.033 & 0.020 & 0.320 & 0.090 & 0.030 & 0.020 & 0.320 & 0.270 \\
\hline fibre & 0.000 & 0.000 & 0.014 & 0.000 & 0.003 & 0.000 & 0.340 & 0.058 & 0.063 & 0.020 & 0.020 & 0.001 & 0.090 & 0.020 & 0.036 & 0.010 \\
\hline interaction & 0.004 & 0.000 & 0.505 & 0.517 & 0.082 & 0.629 & 0.670 & 0.440 & 0.092 & 0.040 & 0.780 & 0.490 & 0.090 & 0.030 & 0.620 & 0.680 \\
\hline
\end{tabular}

SCFA - short chain fatty acids, PP - potato protein, CAS - casein, PEC - pectin, CEL - cellulose, STA - potato starch

Table 3. Total amines concentration $\left(\mu \mathrm{mol} \cdot 100 \mathrm{ml}^{-1}\right)$ after 24 and $48 \mathrm{~h}$ fermentation with colonic and faecal inoculum

\begin{tabular}{|c|c|c|c|c|}
\hline \multirow{2}{*}{$\begin{array}{l}\text { Protein/ } \\
\text { fibre }\end{array}$} & \multicolumn{2}{|c|}{ Colonic inoculum } & \multicolumn{2}{|c|}{ Faecal inoculum } \\
\hline & 24 & 48 & 24 & 48 \\
\hline $\mathrm{PP}^{1} \mathrm{PEC}^{3}$ & 12.56 & 10.36 & 18.52 & 17.64 \\
\hline PP CEL $^{4}$ & 17.22 & 22.54 & 17.72 & 18.32 \\
\hline PP $S T A^{5}$ & 12.24 & 14.68 & 16.64 & 15.49 \\
\hline $\mathrm{CAS}^{2} \mathrm{PEC}$ & 9.04 & 8.08 & 17.00 & 27.87 \\
\hline CAS CEL & 156.57 & 254.59 & 29.83 & 33.71 \\
\hline CAS STA & 58.40 & 65.20 & 33.59 & 61.16 \\
\hline SEM & 20.56 & 20.61 & 2.94 & 8.90 \\
\hline \multicolumn{5}{|l|}{$P$-values } \\
\hline protein & 0.001 & 0.000 & 0.000 & 0.002 \\
\hline fibre & 0.001 & 0.000 & 0.037 & 0.195 \\
\hline interaction & 0.003 & 0.000 & 0.008 & 0.111 \\
\hline
\end{tabular}

1,2,3,4,5 - see Table 2

casein with starch yielded 19,21 and $13 \mu \mathrm{mol} \cdot 100 \mathrm{ml}^{-1}$ of these amines, respectively, and not more after 48 $\mathrm{h}$. The effects of protein on methylamine, cadaverine and histamine, and of fibre on spermidine and phenylethylamine were found only after $48 \mathrm{~h}$. The differences due to type of fibre were more evident when casein was the source of nitrogen.

\section{SCFA and amines concentrations after fermentation with faecal inoculum}

The total SCFA concentration was the smallest on pectin and the greatest on starch, mainly due to the contribution of acetic acid (Table 5). With each fibre it was greater on casein than on potato protein. The type of fibre significantly affected the concentrations of all acids except butyric (after 24 and 48 h), valeric (after $24 \mathrm{~h}$ ) and isovaleric (after $48 \mathrm{~h}$ ) acids, but the differences due to fibre type were small. Protein type only affected the concentration of acetic acid, which after $48 \mathrm{~h}$ of fermentation was higher on casein than on potato protein $(P=0.043)$.

The total amines concentration was greater on casein than on potato protein after $24 \mathrm{~h}$ of fermentation with cellulose and starch $(P=0.008$ for interaction), and also with pectin after $48 \mathrm{~h}$ (Table 3). Prolongation of fermentation of casein, but not of potato protein, with all fibres increased the total amines concentration, mainly due to the increase of tyramine (Table 6).

Table 4. Concentration of amines $\left(\mu \mathrm{mol} \cdot 100 \mathrm{ml}^{-1}\right)$ after 24 and $48 \mathrm{~h}$ fermentation with colonic inoculum

\begin{tabular}{|c|c|c|c|c|c|c|c|c|c|c|c|c|c|c|c|c|}
\hline \multirow{2}{*}{$\begin{array}{l}\text { Protein/ } \\
\text { fibre }\end{array}$} & \multicolumn{2}{|c|}{ Spermidine } & \multicolumn{2}{|c|}{ Methylamine } & \multicolumn{2}{|c|}{ Putrescine } & \multicolumn{2}{|c|}{$\begin{array}{l}\text { Phenylehtyl- } \\
\text { amine }\end{array}$} & \multicolumn{2}{|c|}{ Cadaverine } & \multicolumn{2}{|c|}{ Histamine } & \multicolumn{2}{|c|}{$\begin{array}{l}\text { 1,4-Diamino- } \\
\text { heptane }\end{array}$} & \multicolumn{2}{|c|}{ Tyramine } \\
\hline & 24 & 48 & - & 48 & 24 & 48 & 24 & 48 & 24 & 48 & 24 & 48 & 24 & 48 & 24 & 48 \\
\hline${ }^{1} \mathrm{PEC}^{3}$ & 0.86 & 0.83 & 84 & 1.5 & 1.13 & 1 & 5.81 & 3.72 & 53 & 1. & 3 & 0 & 1.75 & 1.83 & 0.81 & 0.96 \\
\hline$P \mathrm{CEL}^{4}$ & 0.81 & 0.83 & & 1.4 & 2.06 & 5. & 2.99 & 2.83 & 11 & 1. & & $0 . \varepsilon$ & 7.35 & 10.89 & 1.03 & 97 \\
\hline$A^{5}$ & 0.76 & 0.90 & & 1. & & & 2.50 & & & & & & 4.57 & 7 & 5 & 7 \\
\hline $\mathrm{AS}^{2} \mathrm{PEC}$ & 0.78 & 0.77 & 0 & 1.1 & 1.23 & 1 & 2.95 & 2.64 & 2 & & 7 & 2 & 1.43 & 1.29 & 0.69 & 0.96 \\
\hline CAS CEL & 0.90 & 1.01 & 58 & 4.32 & 9.28 & 106.97 & 10.33 & 26.11 & 60 & 4.1 & 2.31 & 7.99 & 69.14 & 108.03 & 1.16 & 1.12 \\
\hline & 0.80 & 1. & & & & & 3.21 & 2 & & & & & 21.36 & 3 & 0.83 & 83 \\
\hline SEM & 0.03 & 0.09 & 23 & 0.52 & 0.39 & 10.93 & 2.33 & 1 & 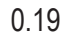 & & 31 & 1.36 & 9.15 & 8.85 & 0.06 & 0.13 \\
\hline \multicolumn{17}{|l|}{$P$-values } \\
\hline & 0.000 & 0.00 & & 0.0 & UL & & 0.010 & 0.000 & & & & & 0.001 & 0.000 & 0.895 & 0.040 \\
\hline fibre & 0.119 & 0.050 & .047 & 0.013 & 0.004 & 40.000 & 0.353 & 0.003 & 0.989 & 0.142 & 0.000 & 0.009 & 0.001 & 0.000 & 0.000 & 0.102 \\
\hline interaction & 0.061 & 0.177 & 0.004 & 0.006 & 0.005 & 50.000 & 0.019 & 0.001 & 0.020 & 0.120 & 0.163 & 0.016 & 0.003 & 0.000 & 0.076 & 0.827 \\
\hline
\end{tabular}




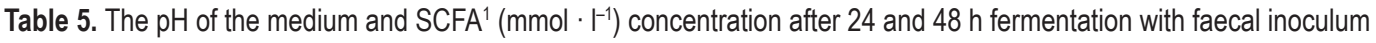

\begin{tabular}{|c|c|c|c|c|c|c|c|c|c|c|c|c|c|c|c|c|}
\hline \multirow{2}{*}{$\begin{array}{l}\text { Protein/ } \\
\text { fibre }\end{array}$} & \multicolumn{2}{|l|}{$\mathrm{pH}$} & \multicolumn{2}{|l|}{$\begin{array}{l}\text { Total } \\
\text { SCFA }\end{array}$} & \multicolumn{2}{|l|}{$\begin{array}{l}\text { Acetic } \\
\text { acid }\end{array}$} & \multicolumn{2}{|c|}{$\begin{array}{l}\text { Propionic } \\
\text { acid }\end{array}$} & \multicolumn{2}{|c|}{$\begin{array}{l}\text { Isobutyric } \\
\text { acid }\end{array}$} & \multicolumn{2}{|c|}{$\begin{array}{l}\text { Butyric } \\
\text { acid }\end{array}$} & \multicolumn{2}{|c|}{$\begin{array}{l}\text { Isovaleric } \\
\text { acid }\end{array}$} & \multicolumn{2}{|c|}{$\begin{array}{l}\text { Valeric } \\
\text { acid }\end{array}$} \\
\hline & 24 & 48 & 24 & 48 & 24 & 48 & 24 & 48 & 24 & 48 & 24 & 48 & 24 & 48 & 24 & 28 \\
\hline $2 \mathrm{PEC}^{3}$ & 3.39 & 3.39 & 2.73 & 2.73 & 1.30 & 1.32 & 0.51 & 0.51 & 0.26 & 0.25 & 0.29 & 0.30 & 0.19 & 0.18 & 0.18 & 0.17 \\
\hline$P \mathrm{CEL}^{5}$ & 4.98 & 5.09 & 3.49 & 3.13 & 1.79 & 1.41 & 0.62 & 0.61 & 0.30 & 0.32 & 0.33 & 0.34 & 0.24 & 0.24 & 0.21 & 0.21 \\
\hline $\mathrm{STA}^{6}$ & 4.11 & 3.90 & 5.18 & 5.45 & 3.59 & 3. & 0.59 & 0 & 0.27 & 0.27 & 0.34 & 0.39 & 0.20 & 0.18 & 0.19 & 0.18 \\
\hline $\mathrm{AS}^{3} \mathrm{PEC}$ & 3.59 & 3.64 & 2.91 & 2.81 & 1.48 & 1.40 & 0.50 & 0.51 & 0.26 & 0.25 & 0.29 & 0.29 & 0.19 & 0.18 & 0.19 & 0.18 \\
\hline AS CEL & 5.57 & 5.44 & 3.51 & 4.07 & 1.83 & 1.8 & 0.59 & 0.60 & 0.30 & 0.35 & 0.32 & 0.61 & 0.27 & 0. & .20 & 27 \\
\hline CAS $S$ & 4.46 & 3.78 & 6.69 & 8.08 & 4.96 & 6.3 & 0.63 & 0.64 & 0.29 & 0.27 & 0.31 & 0.43 & 0.23 & 0.21 & 0.27 & 0.20 \\
\hline SEM & 0.16 & 0.09 & 1.13 & 0.72 & 0.72 & 0.60 & 0.04 & 0.03 & 0.01 & 0.03 & 0.03 & 0.13 & 0.02 & 0.06 & 0.03 & 0.02 \\
\hline \multicolumn{17}{|l|}{$P$-values } \\
\hline & 0.008 & 0.031 & .348 & 0.042 & .510 & 0.0 & & 0.605 & 0.634 & & 0.580 & 0.360 & 0.180 & 0.250 & 0.320 & 0.100 \\
\hline fibre & 0.000 & 0.000 & 0.006 & 0.000 & 0.003 & 0.000 & 0.030 & 0.001 & 0.010 & 0.012 & 0.440 & 0.390 & 0.004 & 0.070 & 0.420 & 0.026 \\
\hline interaction & 0.499 & 0.028 & 0.499 & 0.207 & 0.590 & 0.101 & 0.690 & 0.702 & 0.650 & 0.724 & 0.850 & 0.550 & 0.666 & 0.490 & 0.330 & 0.480 \\
\hline
\end{tabular}

1,2,3,4,5,6 - see Table 2

The concentrations of particular amines were greater, or tended to be greater, on casein than on potato protein, except those of methylamine, putrescine and phenylethylamine, which were not affected by protein (Table 6). The type of fibre affected the concentration of tyramine, which after $24 \mathrm{~h}$ was the smallest when casein was fermented with pectin and the greatest with starch $(P=0.000$ for interaction). The concentration of putrescine was also influenced by the fibre type and was the greatest on pectin both after 24 and $48 \mathrm{~h}$, irrespective of the protein type.

\section{Effects of duration of fermentation and source of inoculum on SCFA and amines concentrations}

The effects of duration of fermentation and type of inoculum were not subjected to statistical analysis and can be merely approximated, therefore, only the most obvious tendencies are presented.

When colonic digesta served as inoculum, prolongation of fermentation of potato starch with both proteins increased the total SCFA concentra- tion mainly due to the increase of acetic and butyric acids, whereas the effects of the experimental factors on the total SCFA concentration after 24 and $48 \mathrm{~h}$ were similar. However, longer fermentation canceled the positive effect of casein on acetic acid and tended to reveal an effect on butyric acid concentrations. The total amines concentration was also affected by the experimental factors in a similar way after 24 and $48 \mathrm{~h}$, whereas particular amines were influenced differently. The effects of protein on spermidine, methylamine, cadaverine and histamine were more evident and statistically confirmed after $48 \mathrm{~h}$ fermentation, whereas the concentrations of putrescine and 1,4-diaminoheptane after fermentation of casein with cellulose were considerably increased. Longer fermentation revealed the effect of fibre on the phenylethylamine concentration.

When faecal inoculum was used as the source of microflora, longer fermentation revealed the effect of interaction on $\mathrm{pH}$ and of protein on total SCFA and acetic acid concentrations. It also showed the effect of fibre type on the valeric acid concentration.

Table 6. Concentration of amines $\left(\mu \mathrm{mol} \cdot 100 \mathrm{ml}^{-1}\right)$ after 24 and $48 \mathrm{~h}$ fermentation with faecal inoculum

\begin{tabular}{|c|c|c|c|c|c|c|c|c|c|c|c|c|c|c|c|c|}
\hline \multirow{2}{*}{$\begin{array}{l}\text { Protein/ } \\
\text { fibre }\end{array}$} & \multicolumn{2}{|c|}{ Spermidine } & \multicolumn{2}{|c|}{ Methylamine } & \multicolumn{2}{|c|}{ Putrescine } & \multicolumn{2}{|c|}{$\begin{array}{l}\text { Phenylehtyl- } \\
\text { amine }\end{array}$} & \multicolumn{2}{|c|}{ Cadaverine } & \multicolumn{2}{|c|}{ Histamine } & \multicolumn{2}{|c|}{$\begin{array}{l}\text { 1,4-Diamino- } \\
\text { heptane }\end{array}$} & \multicolumn{2}{|c|}{ Tyramine } \\
\hline & 24 & 48 & 24 & 48 & 24 & 48 & 24 & 48 & 24 & 48 & 24 & 48 & 24 & 48 & 24 & 48 \\
\hline $\mathrm{PP}^{1} \mathrm{PEC}^{3}$ & 0.93 & 0.92 & 4.26 & 4.68 & 4.88 & 4.03 & 2.88 & 2.22 & 1.36 & 1.35 & 2.69 & 2.81 & 1.04 & 1.01 & 0.48 & 0.62 \\
\hline PP CEL ${ }^{4}$ & 0.87 & 0.87 & 4.60 & 5.07 & 2.73 & 1.46 & 3.36 & 4.15 & 1.75 & 1.96 & 2.71 & 3.04 & 1.03 & 1.07 & 0.67 & 0.70 \\
\hline PP STA ${ }^{5}$ & 0.89 & 0.93 & 4.96 & 5.03 & 1.34 & 1.16 & 3.76 & 3.54 & 1.72 & 1.34 & 2.78 & 2.65 & 1.07 & 1.02 & 0.72 & 0.53 \\
\hline $\mathrm{CAS}^{2} \mathrm{PEC}$ & 0.93 & 0.95 & 4.74 & 4.66 & 3.95 & 4.66 & 3.15 & 2.76 & 1.45 & 1.76 & 2.66 & 2.45 & 1.09 & 1.09 & 0.50 & 12.26 \\
\hline CAS CEL & 1.04 & 1.15 & 4.19 & 3.75 & 1.45 & 1.74 & 5.08 & 5.38 & 10.54 & 10.83 & 5.58 & 4.36 & 1.10 & 1.64 & 1.78 & 5.45 \\
\hline CAS STA & 1.04 & 1.21 & 4.51 & 4.76 & 2.08 & 2.87 & 4.92 & 3.40 & 8.87 & 6.38 & 4.31 & 4.83 & 1.28 & 1.34 & 7.50 & 37.53 \\
\hline SEM & 0.06 & 0.07 & 0.67 & 0.80 & 0.58 & 0.69 & 0.95 & 1.12 & 2.39 & 2.60 & 0.67 & 0.70 & 0.07 & 0.22 & 0.82 & 7.94 \\
\hline \multicolumn{17}{|l|}{$P$-values } \\
\hline protein & 0.051 & 0.002 & 0.818 & 0.416 & 0.316 & 0.140 & 0.183 & 0.556 & 0.009 & 0.030 & 0.011 & 0.076 & 0.059 & 0.078 & 0.000 & 0.009 \\
\hline fibre & 0.852 & 0.169 & 0.877 & 0.831 & 0.001 & 0.001 & 0.315 & 0.135 & 0.117 & 0.191 & 0.101 & 0.217 & 0.216 & 0.391 & 0.000 & 0.110 \\
\hline interaction & 0.362 & 0.136 & 0.734 & 0.689 & 0.235 & 0.636 & 0.744 & 0.829 & 0.164 & 0.279 & 0.107 & 0.200 & 0.513 & 0.563 & 0.000 & 0.106 \\
\hline
\end{tabular}


An effect of protein on total amines, cadaverine and tyramine concentrations was found both after 24 and $48 \mathrm{~h}$ of fermentation. Longer fermentation canceled the effect of protein type on histamine and evidenced its effect on the spermidine concentration. Forty-eight hour fermentation eliminated the effect of fibre on total amines and tyramine concentrations as compared with $24 \mathrm{~h}$.

Fermentation with faecal inoculum yielded lower total SCFA concentrations than with colonic digesta, particularly when potato starch was the substrate. The most striking difference between source of inoculum was the ten-fold lower concentration of butyric acid and considerably lower concentration of valeric acid after faecal fermentation of substrates containing potato starch compared with fermentation with colonic digesta. Moreover, when faecal instead of colonic inoculum was used for fermentation, no effects of protein on the concentrations of acetic (after $24 \mathrm{~h}$ ), propionic (after $48 \mathrm{~h}$ ), isobutyric (after 24 and $48 \mathrm{~h}$ ) and isovaleric (after 24 and 48 h) acids were observed. Moreover, no interactive effects of protein and fibre were found, in contrast with fermentation with colonic digesta.

Inoculum type influenced the total amines concentration only after fermentation of casein. Differences among total amines concentrations after colonic fermentation of casein with three fibres were far greater than after faecal fermentation. The concentrations of particular amines after fermentation with faeces were similar or smaller than after fermentation with colonic digesta, except for methylamine. The differences due to type of inoculum varied among the substrates and amines.

In general, the direct and interactive effects of protein and fibre on the intensity of fermentation and proteolysis were more evident when colonic digesta was used as the inoculum compared with faeces. Prolongation of colonic fermentation increased, whereas faecal incubation decreased the discriminative efficiency of the in vitro test.

\section{Discussion}

The results of our study indicate that the extent and pattern of microbial fermentation and proteolysis in vitro depend directly on the type of fibre and protein and, in some cases, are modified by their interaction. The responses also seem to be influenced by the origin of the inoculum and duration of incubation. Fermentation intensity, as indicated by total SCFA concentrations, was affected by fibre type across all inoculum and time variants, and by protein in all cases except after shorter incubation with faecal inoculum. It was not, however, affected by the interaction of the two substrates.

The consistently highest total SCFA concentration after fermentation of potato starch points to the high fermentability of this carbohydrate and is in agreement with the results of Williams et al. (2001) and Martinez-Puig et al. (2003). The smaller total SCFA concentrations found after fermentation of pectin in comparison with cellulose contrasts with the high fermentability of pectin reported by many authors (McBurney and Thompson, 1989; Casterline et al., 1997) and with the well-established low fermentability of cellulose (Juśkiewicz and Zduńczyk, 2004), which is considered a model 'inert' carbohydrate. It is difficult to explain these conflicting results. The reason may lie in the different physical and/or chemical structure of the compounds used by us and in the reported studies; these differences could have affected their availability to microflora. Whereas the greater total SCFA concentration on cellulose than on pectin was due to the higher concentrations of the majority of particular acids, the highest total SCFA value after fermentation of potato starch was mainly due to the greater concentrations of acetic and butyric acids, which also indicates a different type of fermentation.

The effects of fibre on the intensity of fermentation were more evident after fermentation with colonic than faecal inoculum and after longer than shorter $\mathrm{C}$ fermentation.

In general, after in vitro fermentation of all substrates with colonic digesta, the proportions of acetic, propionic and butyric acids were in the range found in vivo (Taciak et al., 2010). The concentration of butyric acid was the highest after fermentation of potato starch, which confirms the butyrogenic effect of this carbohydrate.

Fermentation with faecal inoculum slightly modified the SCFA profile, with the lower proportions of butyric acid being the most evident. This is in agreement with reports on the lower proportions of this acid found after in vitro fermentation of different fibres with faecal compared with caecal rat inoculum (Monsma and Marlett, 1995), and lower concentrations in faeces than in colonic digesta of pigs fed raw potato starch (Martinez-Puig et al., 2003). All of these findings indicate that the production rate of butyric acid in the hindgut is not uniform and is lower in distal than proximal segments, probably due to differences in microflora composition.

The greater total SCFA concentration after fermentation of casein shows that the non-pre-digested 
casein was a more available substrate for microflora than potato protein. The more intensive microbial degradation of casein was confirmed by the greater total concentration of amines, but only when it was fermented with cellulose, and, to a smaller extent, with potato starch.

Amines are potentially toxic and carcinogenic compounds formed in the hindgut by decarboxylation of amino acids during microbial proteolysis (Hughes et al., 2000; Blachier et al., 2007). It is hypothesized that production of amines is greater when the supply of fermentable carbohydrates is low and undigested protein is used as an energy source. In our study, more intensive proteolysis of casein when fermented with cellulose than with starch and pectin was evidenced by the respective greatest total amine concentration, but only after incubation with colonic digesta. This finding is in line with the documented low value of cellulose as an energy source for microflora, leading to more intensive fermentation of protein for energy purposes. It may be concluded that fibre sources containing cellulose stimulate, whereas those containing pectin or, to lesser extent, resistant starch, restrain bacterial formation of amines from easily available protein. It should be, however, stressed that this interpretation is valid only for casein and only when colonic digesta was the source of microflora in vitro.

Studies on amines as products of proteolysis are scarce and their results do not always support the hypothesis on the sparing effect of fermentable carbohydrates on protein catabolism (Bailey et al., 2002; Swanson et al., 2002; Jeaurond et al., 2008; Kim et al., 2008). The diversity of these results may be partly explained by different experimental methods, including the origin of sampled material or inoculum. The use of faecal inoculum in in vitro studies of fermentation is a common practice (Coles et al., 2005) and faeces are treated as the obvious source of colonic bacteria (Jha et al., 2011; Bliss et al., 2013). Our results showing that fermentation with colonic digesta yields greater total SCFA concentrations and is more discriminative than fermentation with fresh faecal inoculum, agree with the results of Monsma and Marlett (1995) who found greater initial and maximum production of SCFA after fermentation with caecal than faecal inoculum in rat model. Similarly, in both studies production of butyric acid from starch was greater when colonic rather than faecal inoculum was employed. These findings correspond with the greater trophic effects of fermentation products in the proximal than in the distal large bowel and support the reservations formulated by Monsma and Marlett (1995) on extrapolating SCFA production by faecal inoculum to the proximal colon. Our results, particularly the more evident effects of protein and fibre on SCFA and more differentiated concentration of amines produced from casein after colonic than faecal fermentation, lead to the conclusion that faecal inoculum is less useful than colonic inoculum in in vitro studies.

The $24 \mathrm{~h}$ incubation time used in the majority of in vitro studies on the fermentability of different fibre sources corresponds to the average transit rate of digesta along the proximal colon in humans (Coles et al., 2005). It is suggested that longer incubation may be subject to the negative effects of end products and inhibition of microbial activity. In our study, we employed an additional $24 \mathrm{~h}$ period (total $48 \mathrm{~h}$ ) as this is close to the average transit time in the gastrointestinal tract of pigs (around $44 \mathrm{~h}$ ), of which about $40 \mathrm{~h}$ is the large intestine (Jha et al., 2011).

The rate of carbohydrate fermentation in the gut is important since rapid fermentation causes production of gases, whereas slow fermentation provides SCFA (particularly butyric acid) over a longer time and to distal parts of the hindgut (Kaur et al., 2011). According to Casterline et al. (1997), SCFA production during the in vitro fermentation of various fibres differs in the initial $(6 \mathrm{~h})$, medium $(24 \mathrm{~h})$ and longer $(48 \mathrm{~h})$ periods. In our study, the greatest total SCFA and butyric acid concentrations after fermentation of potato starch both after $24 \mathrm{~h}$ and $48 \mathrm{~h}$ means that resistant starch is fermented intensively, but for a relatively long time and may have beneficial effects along the gut. On the other hand, prolongation of colonic incubation of casein with cellulose resulted in a substantial increase of amines, whereas no such increase was observed when casein was fermented with pectin, and only a very small one with starch. It may, therefore, be expected that the negative effects of prolongation of protein fermentation in the gut depend to a great extent on the type of fibre and may be small when protein is combined with a fermentable fibre.

In general, prolongation of incubation tended to amplify the differences due to protein and fibre, but this effect was not consistent. A significant influence of protein on total SCFA was found or confirmed statistically only after $48 \mathrm{~h}$ fermentation with both inocula, whereas the effects of fibre and of protein and fibre interaction on total amines concentrations were found after faecal fermentation, but only after $24 \mathrm{~h}$. 


\section{Conclusions}

The direct and interactive effects of type of protein and fibre on the outcome of in vitro fermentation depend on the source of inoculum and duration of incubation. Colonic digesta appears to be more discriminative than faecal inoculum, since some important findings, as the butyrogenic effect of resistant starch, were confirmed after colonic fermentation, but were absent after faecal fermentation. The effects of fermentation duration are not consistent. Prolongation of colonic incubation tends to magnify the effects of protein and fibre on concentrations of carbohydrate and protein metabolites, whereas longer incubation with faecal inoculum tends to reduce these effects. It may be postulated that at least two incubation times should be employed to obtain valid data on the outcome of in vitro fermentation of carbohydrate and protein.

The lower concentration of amines after fermentation of casein with starch and pectin than with cellulose supports the hypothesis on the dependency of bacterial proteolysis on the supply of energy from carbohydrates. It may be concluded that fermentable fibres may help to reduce the concentration of potentially toxic protein metabolites in colonic digesta, particularly high during longer fermentation.

Our results indicate that in vitro simulation of protein and carbohydrate fermentation in the large intestine of pigs gives valuable information, especially using colonic digesta as the inoculum and $48 \mathrm{~h}$ incubation. Moreover, it can be concluded that faecal inoculum does not represent colonic microflora and is less useful in in vitro studies.

\section{Acknowledgement}

This study was financially supported by the Ministry of Science and Higher Education of Poland, Grant No. N N311 046634.

Authors wish to thank Łukasz Staśkiewicz and Martyna Tołpa for their valuable analytical assistance.

\section{References}

Bailey S.R., Marr C.M., Elliot J., 2003. Identification and quantification of amines in the equine caecum. Res. Vet. Sci. 74, 113-118

Bailey S.R., Rycroft A., Elliott J., 2002. Production of amines in equine cecal contents in an in vitro model of carbohydrate overload. J. Anim. Sci. 80, 2656-2662

Barszcz M., Taciak M., Skomiał J., 2011. A dose-response effects of tannic acid and protein on growth performance, caecal fermentation, colon morphology, and $\beta$-glucuronidase activity of rats. J. Anim. Feed Sci. 20, 613-625
Bindelle J., Leterme P., Buldgen A., 2008. Nutritional and environmental consequences of dietary fibre in pig nutrition: a review. Biotechnol. Agron. Soc. Environ. 12, 69-80

Blachier F., Mariotti F., Huneau J.F., Tomé D., 2007. Effects of amino acid-derived luminal metabolites on the colonic epithelium and physiopathological consequences. Amino Acids 33, 547-562

Bliss D.Z., Weimer P.J., Jung H.-J.G., Savik K., 2013. In vitro degradation and fermentation of three dietary fiber sources by human colonic bacteria. J. Agr. Food Chem. 61, 4614-4621

Bourquin L.D., Titgemeyer E.C., Garleb K.A., Fahey G.C., 1992. Shortchain fatty acid production and fiber degradation by human colonic bacteria: effects of substrate and cell wall fractionation procedures. J. Nutr. 122, 1508-1520

Campbell J.M., Fahey Jr. G.C., 1997. Psyllium and methylcellulose fermentation properties in relation to insoluble and soluble fiber standards. Nutr. Res. 17, 619-629

Casterline J.L., Oles C.J., Ku Y., 1997. In vitro fermentation of various food fiber fractions. J. Agr. Food Chem. 45, 2463-2467

Coles L.T., Moughan P.J., Darragh A.J., 2005. In vitro digestion and fermentation methods, including gas production techniques, as applied to nutritive evaluation of foods in the hindgut of humans and simple-stomached animals. Anim. Feed Sci. Tech. 123-124, 421-444

Dierick N., Ovyn A., De Smet S., 2010. In vitro assessment of the effect of intact marine brown macro-algae Ascophyllum nodosum on the gut flora of piglets. Livest. Sci. 133, 154-156

Hughes R., Magee E.A.M, Bingham S., 2000. Protein degradation in the large intestine: relevance to colorectal cancer. Curr. Issues Intest. Microbiol. 1, 51-58

Jeaurond E.A., Rademacher M., Pluske J.R., Zhu C.H., de Lange C.F.M., 2008. Impact of feeding fermentable proteins and carbohydrates on growth performance, gut health and gastrointestinal function of newly weaned pigs. Can. J. Anim. Sci. $88,271-281$

Jha R., Bindelle J., Van Kessel A., Leterme P., 2011. In vitro fibre fermentation of feed ingredients with varying fermentable carbohydrate and protein levels and protein synthesis by colonic bacteria isolated from pigs. Anim. Feed Sci. Tech. 165, 191-200

Juśkiewicz J., Zduńczyk Z., 2004. Effects of cellulose, carboxymethylcellulose and inulin fed to rats as single supplements or in combinations on their caecal parameters. Comp. Biochem. Phys. Pt. A 139, 513-519

Kaur A., Rose D.J., Rumpagaporn P., Patterson J.A., Hamaker B.R., 2011. In vitro batch fecal fermentation comparison of gas and short-chain fatty acid production using 'slowly fermentable' dietary fibers. J. Food Sci. 76, H137-H142

Kim J.C., Mullan B.P., Hampson D.J., Pluske J.R., 2008. Addition of oat hulls to an extruded rice-based diet for weaner pigs ameliorates the incidence of diarrhoea and reduces indices of protein fermentation in the gastrointestinal tract. Brit. J. Nutr. 99, 1217-1225

Mallillin A.C., Trinidad T.P., Raterta R., Dagbay K., Loyola A.S., 2008. Dietary fibre and fermentability characteristics of root crops and legumes. Brit. J. Nutr. 100, 485-488

Martinez-Puig D., Pérez J.F., Castillo M., Andaluz A., Anguita M., Morales J., Gasa J., 2003. Consumption of raw potato starch increases colon length and fecal excretion of purine bases in growing pigs. J. Nutr. 133, 134-139

McBurney M.I., Thompson L.U., 1989. In vitro fermentabilities of purified fiber supplements. J. Food Sci. 54, 347-350

Monsma D.J., Marlett J.A., 1995. Rat cecal inocula produce different patterns of short-chain fatty acids than fecal inocula in in vitro fermentations. J. Nutr. 125, 2463-2470 
Montagne L., Pluske J.R., Hampson D.J., 2003. A review of interactions between dietary fibre and the intestinal mucosa, and their consequences on digestive health in young non-ruminant animals. Anim. Feed Sci. Tech. 108, 95-117

Morita T., Kasaoka S., Kiriyama S., 2004. Physiological functions of resistant proteins: proteins and peptides regulating large bowel fermentation of indigestible polysaccharide. J. AOAC Int. 87, 792-796

Morita T., Kasaoka S., Oh-hashi A., Ikai M., Numasaki Y., Kiriyama S., 1998. Resistant proteins alter cecal short-chain fatty acid profiles in rats fed high amylose cornstarch. J. Nutr. 128,11561164

Pieper R., Kröger S., Richter J.F. et al., 2012. Fermentable fiber ameliorates fermentable protein-induced changes in microbial ecology, but not the mucosal response, in the colon of piglets. J. Nutr. 142, 661-667

Richter J.F., Pieper R., Zakrzewski S.S., Günzel D., Schulzke J.D., Van Kessel A.G., 2013. Diets high in fermentable protein and fibre alter tight junction protein composition with minor effects on barrier function in piglet colon. Brit. J. Nutr. 111, 1040-1049
Swanson K.S., Grieshop C.M., Flickinger E.A., Bauer L.L., Healy H.P., Dawson K.A., Merchen N.R., Fahey G.C., 2002. Supplemental fructooligosaccharides and mannanoligosaccharides influence immune function, ileal and total tract nutrient digestibilities, microbial populations and concentrations of protein catabolites in the large bowel of dogs. J. Nutr. 132, 980-989

Tabernero M., Venema K., Maathuis A.J.H., Saura-Calixto F.D., 2011. Metabolite production during in vitro colonic fermentation of dietary fiber: analysis and comparison of two European diets. J. Agr. Food Chem. 59, 8968-8975

Taciak M., Pastuszewska B., Tuśnio A., Święch E., 2010. Effects of two protein and fibre sources on SCFA concentration in pig large intestine. Livest. Sci. 133, 138-140

Tuśnio A., Pastuszewska B., Święch E., Taciak M., 2011. Response of young pigs to feeding potato protein and potato fibre - nutritional, physiological and biochemical parameters. J. Anim. Feed Sci. 20, 361-378

Williams B.A., Verstegen M.W.A., Tamminga S., 2001. Fermentation in the large intestine of single-stomached animals and its relationship to animal health. Nutr. Res. Rev. 14, 207-227 